IZA DP No. 6291

Innovation, Employment and Skills in Advanced and Developing Countries: A Survey of the Literature

Marco Vivarelli

January 2012 


\title{
Innovation, Employment and Skills in Advanced and Developing Countries: A Survey of the Literature
}

\author{
Marco Vivarelli \\ Università Cattolica del Sacro Cuore, \\ SPRU, University of Sussex and IZA
}

Discussion Paper No. 6291

January 2012

IZA

P.O. Box 7240

53072 Bonn

Germany

Phone: +49-228-3894-0

Fax: +49-228-3894-180

E-mail: iza@iza.org

\begin{abstract}
Any opinions expressed here are those of the author(s) and not those of IZA. Research published in this series may include views on policy, but the institute itself takes no institutional policy positions.

The Institute for the Study of Labor (IZA) in Bonn is a local and virtual international research center and a place of communication between science, politics and business. IZA is an independent nonprofit organization supported by Deutsche Post Foundation. The center is associated with the University of Bonn and offers a stimulating research environment through its international network, workshops and conferences, data service, project support, research visits and doctoral program. IZA engages in (i) original and internationally competitive research in all fields of labor economics, (ii) development of policy concepts, and (iii) dissemination of research results and concepts to the interested public.
\end{abstract}

IZA Discussion Papers often represent preliminary work and are circulated to encourage discussion. Citation of such a paper should account for its provisional character. A revised version may be available directly from the author. 


\section{ABSTRACT \\ Innovation, Employment and Skills in Advanced and Developing Countries: A Survey of the Literature ${ }^{*}$}

This paper critically discusses the theoretical and empirical literature on the quantitative and qualitative employment impact of technological change, compares the relative explanatory power of the competing theories, and explains in detail the macro and micro evidence on the issue, with reference both to the advanced economies and the developing countries (DCs).

JEL Classification: $\quad 033$

Keywords: technology, innovation, employment, skill, skill-biased technological change

Corresponding author:

Marco Vivarelli

Università Cattolica del Sacro Cuore

Facoltà di Economia

via Emilia Parmense 84

29100 Piacenza

Italy

E-mail: marco.vivarelli@unicatt.it

\footnotetext{
* This paper is part of the project RG-K1164 "Employment Generation, Firm Size and Innovation in Latin America: The Microeconometric Evidence" coordinated by the Science and Technology Division of the Inter-American Development Bank (IDB). This document was originally published as an IDB Technical Note, IDB-TN-351, and can also be found at http://www.iadb.org/publications/search.cfm? docType=Technical\%20Notes. The Inter-American Development Bank Technical Notes encompass a wide range of best practices, project evaluations, lessons learned, case studies, methodological notes, and other documents of a technical nature. The information and opinions presented in these publications are entirely those of the author(s), and no endorsement by the Inter-American Development Bank, its Board of Executive Directors, or the countries they represent is expressed or implied.
} 


\section{INTRODUCTION}

The possible adverse effect of technological change on employment and the possibility to counterbalance the initial displacement of jobs are old and controversial issues:

"Machines cannot be constructed without considerable labor, which gives occupation to the hands they throw out of employ" (Say, 1964: 87).

Historically, the fear of technological unemployment has always emerged in ages characterized by radical technological changes. For instance, the striking response of the English workers to the first industrial revolution was the destruction of machines under the charismatic lead of Ned Ludd in the industrial areas and of Captain Swing in the countryside (see Hobsbawm, 1968; Hobsbawm and Rudé, 1969).

On the other hand, since its very beginning, the economic theory has pointed out the existence of economic forces, which can spontaneously compensate for the reduction in employment due to technological progress. In other words, using Ricardo's words, the "working class opinion" was characterized by the fear of being dismissed because of technical change, whilst the academic and political debate was mainly dominated by an exante confidence in the market compensation of dismissed workers:

"I have before observed, too, that the increase of net incomes, estimated in commodities, which is always the consequence of improved machinery, will lead to new saving and accumulation” (Ricardo, 1951: 396).

It is interesting that nowadays - mutatis mutandis - the present economic debate about the employment impact of innovation is still characterized by a focus on those market compensation forces, which can counterbalance the initial labor-saving effect of process innovation. Yet, recent economic analyses have also singled out two other important aspect of the relationship between technological change and employment: on the one hand, the possible labor-friendly impact of product innovation, as opposed to process innovation; on the other hand the possible "qualitative" effect of innovation (in terms of its skill bias) as opposed to the sole "quantitative" effect in terms of possible displacement of workers. Of course, product and process innovation are not the sole and isolated sources of employment change and skill bias. Although is it out of the scope of the present contribution, organizational change (see Caroli, Greenan and Guellec, 2001; Bresnahan, Brynjolfsson and Hitt, 2002) and management practices (see Bloom and Van Reenen, 2010) are 
important mediating factors in driving the final quantitative and qualitative employment impact of innovation. In particular, important "Edgeworth externalities" may arise in the interaction between technological and organizational change, generating "superadditive" (see Milgrom and Roberts, 1990 and 1995) effects in terms of employment levels and skillupgrading. ${ }^{1}$ This paper critically discusses the theoretical and empirical literature on the quantitative and qualitative employment impact of technological change, compares the relative explanatory power of the competing theories, and explains the macro and micro evidence on the issue. In particular, the next section is devoted to the so-called "theory of compensation," a classical theory which is still the basis of current economic models that try to understand the employment impact of innovation. In light of the classical taxonomy, Section 3 presents a survey of the available empirical evidence on the relationship between innovation and employment at the macro, sectoral, and micro levels. Section 4 introduces the literature on the so-called "skill-biased technological change." Section 5 focuses on the analysis on the developing countries (DCs), and Section 6 concludes.

\section{INNOVATION AND EMPLOYMENT: THE THEORY}

By definition, technological change allows to produce the same amount of goods with a lower amount of production factors, namely capital and labor. Interestingly enough, "technological unemployment" occurs as a direct effect of innovation irrespective of its intrinsic nature. Assuming the Hicksian distinction between neutral, labor-saving and capitalsaving technological change, Figures 1, 2, and 3 show that employment in absolute terms always decreases as a direct effect of technological change. Starting from the equilibrium E-where a given amount of output $(\bar{y})$ is produced by the full potential levels of capital ( $\overline{\mathrm{K}}_{\mathrm{p}}$ ) and labor ( $\left.\overline{\mathrm{L}}_{\mathrm{p}}\right)$ - technological change allows a shift of the isoquant towards the origin. At the same levels of wages (w) and rates of interest (r), the new equilibrium shifts to $E$ ', requiring the new levels of inputs $\hat{\mathrm{K}}$ and $\hat{\mathrm{L}}$. As can be seen, $\hat{\mathrm{L}}$ is always lower than $\overline{\mathrm{L}}_{\mathrm{p}}$ irrespective of innovation being neutral, labor-saving or capital-saving. ${ }^{2}$

\footnotetext{
${ }^{1}$ Although organizational change is very difficult to be defined and measured, recent literature has empirically proven that the so-called "skill-biased organizational change" is as important as the "skill-biased technological change” (see, for instance, Caroli and Van Reenen, 2001; Greenan, 2003; Piva, Santarelli, and Vivarelli, 2005). 2 The only possible exception is a so drastic capital-saving innovation able to move the equilibrium E' to the right of the initial level of employment.
} 
Figure 1: Neutral Technological Change

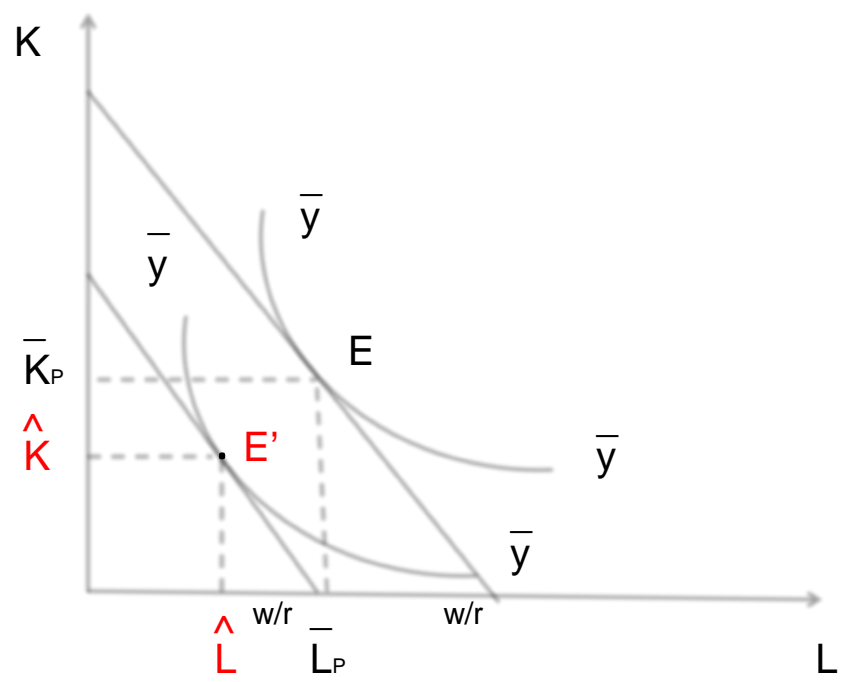

Figure 2: Labor-saving Technological Change

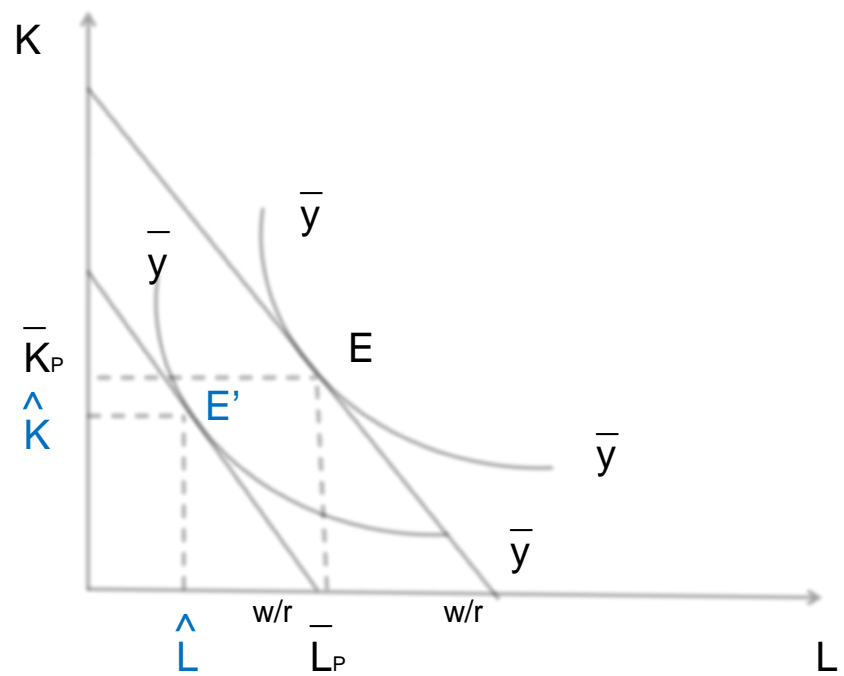




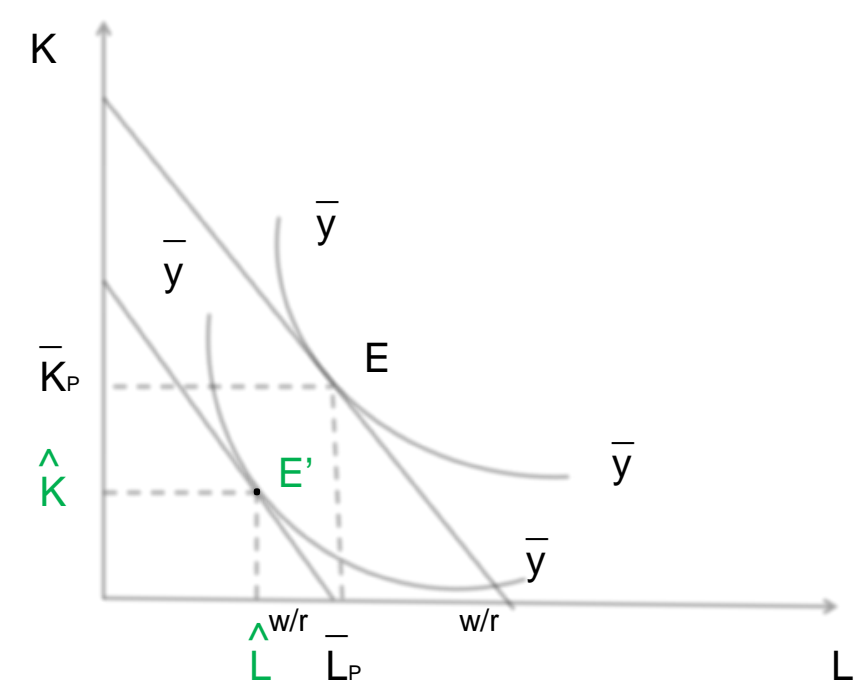

The figures above represent only the "direct" effect of technological change, and particularly of process innovation. Indeed, the economic discipline-since its foundationhas tried to dispel the concerns about the direct harmful effects of technological change pointing out both the market mechanisms able to counterbalance the direct impact of process innovation and the job creating effects of product innovation. Thus, in the first half of the $19^{\text {th }}$ century — while the Luddites were destroying the new machines - economists put forward a theory that Marx later called the "compensation theory” (see Marx, 1961: chap. 13; Marx, 1969: chap. 18). This theory is made up of six different market compensation mechanisms that are triggered by technical change itself and which can counterbalance the initial laborsaving impact of process innovation (for an extensive analysis, see also Vivarelli, 1995: chaps. 2 and 3; Petit, 1995; Vivarelli and Pianta, 2000: chap. 2; Pianta, 2005).

1) The compensation mechanism "via additional employment in the capital goods sector."

The same process innovations that displace workers in the user industries create new jobs in the capital sectors where the new machines are produced (see, for instance, Say, 1964, first ed. 1803). 
2) The compensation mechanism "via decrease in prices."

On the one hand, process innovations involve the displacement of workers; on the other hand, these innovations themselves lead to a decrease in the unit costs of production and-in a competitive market—-this effect is translated into decreasing prices; in turn, decreasing prices stimulate a new demand for products and so additional production and employment. This mechanism was singled out at the very beginning of the history of the economic thought:

"The introduction of machines is found to reduce prices in a surprising manner. And if they have the effect of taking bread from hundreds, formerly employed in performing their simple operations, they have that also of giving bread to thousands" (Steuart, 1966: 256).

Indeed, the compensation mechanism "via decrease in prices" has been reproposed many times in the history of economic thought both by neoclassical economists at the beginning of this century (see Clark, 1907: 270; Pigou, 1962: 672) and by modern theorists (see Heffernan, 1981; Neary, 1981; Stoneman, 1983a: chaps. 11 and 12; Hall and Heffernan, 1985; Dobbs, Hill and Waterson, 1987; Nickell and Kong, 1989; for a detailed analysis of the hypotheses, procedures and conclusions of these models, see Vivarelli, 1995: chaps. 4 and 6).

\section{3) The compensation mechanism "via new investments"}

In a world where the competitive convergence is not instantaneous, during the gap between the decrease in costs-due to technical progress-and the consequent fall in prices, innovative entrepreneurs may accumulate extra profits. These profits are invested, which leads to new productions and new jobs. Originally put forward by Ricardo (1951), this proposition has also been called forth by marginalist economists like Marshall (1961: 542) and Douglas (1930: 936) and by recent dynamic models such as those by Hicks (1973) and Stoneman (1983a: 177-81; 1983b).

\section{4) The compensation mechanism "via decrease in wages."}

As with other forms of unemployment, the direct effect of labor-saving technologies may be compensated within the labor market through a proper price adjustment. In a neoclassical framework-with free competition and full substitutability between 
labor and capital —a decrease in wages leads to an increase in the demand for labor. The first to apply this kind of argument to the specific case of technological unemployment was Wicksell (1961: 137), followed by Hicks (1932: 56), Pigou (1933: 256) and Robbins (1934: 186).

In modern times, the wage adjustment is a component of partial equilibrium models, such as those by Neary (1981) and Sinclair (1981) and generally equilibrium analyses such as those by Layard and Nickell (1985), Venables (1985) and Layard, Nickell and Jackman (1991; 1994).

\section{5) The compensation mechanism "via increase in incomes."}

Directly in contrast with the previous one, this compensation mechanism has been put forward by the Keynesian and Kaldorian tradition. In a Fordist mode of production, unions take part in the distribution of the fruits of technical progress. Thus, it has to be taken into account that a portion of the cost savings due to technical change can be translated into higher incomes and hence higher consumption. This increase in demand leads to an increase in employment, which may compensate the initial job losses due to process innovations (see Pasinetti, 1981; Boyer, 1988a; 1988b; 1990).

\section{6) The compensation mechanism "via new products."}

Technical change is not equivalent to process innovation, but it can assume the form of creation and commercialization of new products; in this case, new economic branches develop and additional jobs are created. Once again, classical economists (Say, 1964: 88) have underlined the labor-intensive impact of product innovations, and even the most severe critic of compensation theory have admitted the positive employment benefits that can derive from this kind of technical progress:

"Entirely new branches of production, creating new fields of labor, are also formed, as the direct result either of machinery or of the general industrial changes brought about by it." (Marx, 1961: 445).

In the current debate, various studies (Freeman, Clark and Soete, 1982; Freeman and Soete, 1987 and 1994; Vivarelli and Pianta, 2000; Edquist, Hommen and McKelvey, 2001) agree that product innovations have a positive impact on employment since they allow for the development of either entire new goods or main differentiation of mature goods. In the latter 
case, the "welfare effect" (new branches of production) has to be compared with the "substitution effect” (displacement of mature products) (see Katsoulacos 1984; 1986). ${ }^{3}$

On the whole, economic theory clarifies those market forces that can potentially counterbalance the initial labor-saving impact of process innovation; moreover, it is recognized that the alternative form of technological change-namely the diffusion of entirely new products - can imply an obvious job-creating effect. On the other hand, compensation mechanisms can be hindered-or even annihilated-by the existence of important drawbacks. Using the same taxonomy proposed above, the main criticisms of the compensation theory can be singled out as follows.

A) With few exceptions (see Hicks, 1973), nowadays the compensation mechanism "via additional employment in the capital good sector" is not put forward. Indeed, Marx's critique of this mechanism was so sharp that it stopped this first line of reasoning of the compensation theory: “(...) the machine can only be employed profitably, if it...is the (annual) product of far fewer men than it replaces” (Marx, 1969: 552). Moreover, labor-saving technologies spread around in the capital goods sector, as well; so this compensation is an endless story which can be only partial (Marx, 1969: 551).

Finally, the new machines can be implemented either through additional investments (see point $\mathrm{C}$ ) or simply by substitution of the obsolete ones (scrapping). In the latter case-which is indeed the most frequent one- there is no compensation at all (see, for instance, Freeman, Clark and Soete, 1982).

B) As originally noted by Malthus (1964: 551-60) and Sismondi (1971: 284), the very first effect of labor-saving process innovation is a decrease in the aggregate demand due to the cessation of the demand previously associated with the dismissed workers. So, the mechanism "via decrease in prices" deals with a decreased demand and has to more than counterbalance the initial decrease in the aggregate purchasing power as noted by Mill (1976: 97):

\footnotetext{
${ }^{3}$ New products and the correspondent new employment can be introduced by either incumbent firms or by new entrepreneurial firms that enter the market based on innovative ideas. Indeed, the entrepreneurial literature show that those new firms which are created around the introduction of an innovative product are those that survive the most and create more employment (see Arrighetti and Vivarelli, 1999; Cefis and Marsili, 2005; 2006).
} 
“(..) the increased demand for commodities by some consumers, will be balanced by a cessation of demand on the part of others, namely, the laborers who were superseded by the improvement."

In addition, this mechanism relies on Say's law and does not take into account that demand constraints might occur. Difficulties concerning the components of the "effective demand," such as a low value of the "marginal efficiency of capital” (see Keynes, 1973: chap. 11) can involve a delay in expenditure decisions and a lower demand elasticity. If such is the case, this compensation mechanism is hindered and technological unemployment ceases to be a temporary problem (for a detailed criticism about compensation based on Say's law, see also Standing, 1984: 131-33).

Finally, the effectiveness of the mechanism "via decrease in prices" depends on the hypothesis of perfect competition. If an oligopolistic regime is dominant, the whole compensation is strongly weakened since cost savings are not necessarily and entirely translated into decreasing prices (see Sylos Labini, 1969: 160).

C) Also the compensation mechanism “via new investments" relies on the Say's law assumption that the accumulated profits due to technical change are entirely and immediately translated into additional investments. Again, Marx's and Keynes's treatment of Say's law can be used against the full effectiveness of this compensation mechanism. In other words, the theoretical analysis has to take into account the "animal spirits" and the economic agents' expectations, which can delay the translation of additional profits into "effective demand" (see Pasinetti, 1981; Freeman and Soete, 1987; Vivarelli, 1995; Appelbaum and Schettkat, 1995; Pianta, 2005). Moreover, the intrinsic nature of the new investments does matter; if these are capitalintensive, compensation can only be partial:

“The accumulation of capital, though originally appearing as its quantitative extension only, is effected, as we have seen, under a progressive qualitative change in its composition, under a constant increase of its constant, at the expense of its variable constituent” (Marx, 1961: 628).

D) Also the mechanism "via decrease in wages" collides with the Keynesian theory of effective demand. On the one hand, a decrease in wages can induce firms to hire 
additional workers, but — on the other hand — the decreased aggregate demand lowers the employers' expectations and so they tend to hire fewer workers.

A second criticism can be launched to this mechanism if the cumulative and irreversible nature of modern technical change is properly taken into account (see Rosenberg, 1976; Dosi, 1988). In this view, science and technology have their own rules: along a "technological trajectory," "localized technical progress" occurs, and this can give rise to "locked in" technologies (see Stiglitz, 1987: 128; Freeman and Soete, 1987: 42). If the cumulative and localized nature of technical change is taken into account, the hypothesis of perfect substitutability between capital and labor assumed by neoclassical models appears to be quite arbitrary. At the same time:

“(...) there is inherent plausibility in the Hicks inducement theory, biasing the long term direction of technical change in a labor-saving direction. Attempts to generate a reversal of this trend by temporary small reductions in the relative price of labor are extremely unlikely to be effective" (Freeman and Soete, 1987: 46).

E) During the "golden age" of the 1950s and 1960s, the Fordist mode of production was based on a relevant change in the labor-wage nexus. Instead of leaving the wage to be regulated by a competitive labor market, workers could possess a relevant portion of productivity gains due to technical progress. In turn, the increased real wages involved mass consumption and this stimulated investments leading to further productivity gains through technical progress and scale economies (Boyer, 1988c; 1988d). Labor-saving technologies were introduced on a large scale, but the Kaldorian "virtuous circle” allowed an important compensation "via new incomes." The Fordist mode of production is no longer relevant for many reasons, which warrant a separate discussion (see Boyer 1988c; 1990). The distribution of income follows different rules and the labor market is competitive once again. On the whole, this compensation mechanism has been strongly weakened in the new institutional context.

F) New products are still the most powerful way to counterbalance labor-saving process innovations. Yet, different "technological paradigms” (see Dosi, 1982) are characterized by different clusters of new products, which in turn have very different impacts on employment. So, the introduction of the automobile had a much higher 
labor-intensive effect than the diffusion of the home computers. As a matter of fact, in different historical periods and different institutional frameworks, the relative balance between the labor-saving effect of process innovations and the labor-intensive impact of product innovations can vary considerably. Moreover, product and process innovations often come together, since the latter can be a necessary complement of the former; ${ }^{4}$ therefore, the final impact in terms of employment turns out to be an open empirical matter (see below).

In conclusion, the relationship between innovation and employment can be represented by a very complex picture where the direct labor-saving impact of process innovation, the compensation mechanisms, the drawbacks and hindrances which can severely weaken the effectiveness of such mechanisms, and the labor friendly nature of product innovation can combine in very diverse outcomes.

While the "end of work" popular approach (see Rifkin, 1995) erroneously underestimates the opportunities for compensation, economists sometimes forget that compensation can only be partial and that it is dependent on particular historical and institutional circumstances. A well-balanced and sensible conclusion about the compensation theory can be quoted from Pasinetti (1981: 90):

"For the time being, we may draw the important conclusion that the structural dynamics of the economic system inevitably tend to generate what has rightly been called technological unemployment. At the same time, the very same structural dynamics produce counter-balancing movements which are capable of bringing macro-economic condition...towards fulfillment, but not automatically."

Indeed, as it emerges from the discussion so far, economic theory does not have a clear-cut answer about the employment effect of innovation. Thus, attention should be turned to aggregate, sectoral, and microeconomic empirical analyses, which should consider the different forms of technical change, their direct effects on labor, the various compensation mechanisms, and the possible hindrances to these mechanisms.

\footnotetext{
${ }^{4}$ Indeed, at the micro level, the European Community Innovation Surveys clearly show that the vast majority of innovative firms are jointly involved in both product and process innovation (see, for instance, ISTAT, 1997).
} 


\section{INNOVATION AND EMPLOYMENT: THE EMPIRICAL EVIDENCE}

Whilst theoretical economists may develop clear models about the employment impact of process and product innovation, applied economists have to "measure" process and product innovation, the compensation mechanisms, and the final employment impact of innovation; from this respect, at least three main problems arise.

1) Innovation is difficult to measure; traditional indicators such as research and development (R\&D) (input indicator), patents and relevant innovation (output indicators) are seldom fully available and are often inadequate to fully represent technological progress. For instance, most of process innovation is implemented through "embodied technological change” (ETC), ${ }^{5}$ in turn introduced through gross investment. This technological input is often more important than R\&D activities; think for instance about the traditional sectors and small and medium enterprises (SMEs), where in-house R\&D has a very limited role and conversely most of innovation is introduced through the acquisition of capital goods. In terms of Pavitt (1984) taxonomy, technological change in the "supplier dominated" firms is much more dependent on machineries acquired by the "specialized suppliers" than from their own R\&D expenditures. These circumstances are obviously quite crucial in the DCs (see Section 5). Figure 4 presents the two faces of innovation, with R\&D mainly correlated with the labor-friendly product innovation and ETC mainly related to the labor-saving process innovation. Indeed, recent microeconometric studies-using data from the European Community Innovation Surveys (CIS) - have confirmed empirically how R\&D expenditures are closely linked with product innovation, while innovative investment (especially devoted to new machinery and equipment incorporating ETC) is related to process innovation (see Conte and Vivarelli, 2005; Parisi, Schiantarelli and Sembenelli, 2006). In sum, a proper mapping of innovation inputs and outputs is crucial in trying to empirically estimate the employment consequences of technological change.

\footnotetext{
${ }^{5}$ The embodied nature of technological progress and the effects related to its spread in the economy were originally discussed by Salter (1960) and Solow (1960) who underlined that technological progress might be incorporated in new vintages of capital introduced either through additional investment or simply by scrapping. More recently, growth theorists have recognized the role of capital accumulation in fostering productivity growth and economic developmen (see Hulten, 1992; Greenwood, Hercowitz, and Krusell, 1997; Hercowitz, 1998; Abowd, Haltiwanger, Lane, McKinney and Sandusky, 2007; Wilson, 2009).
} 


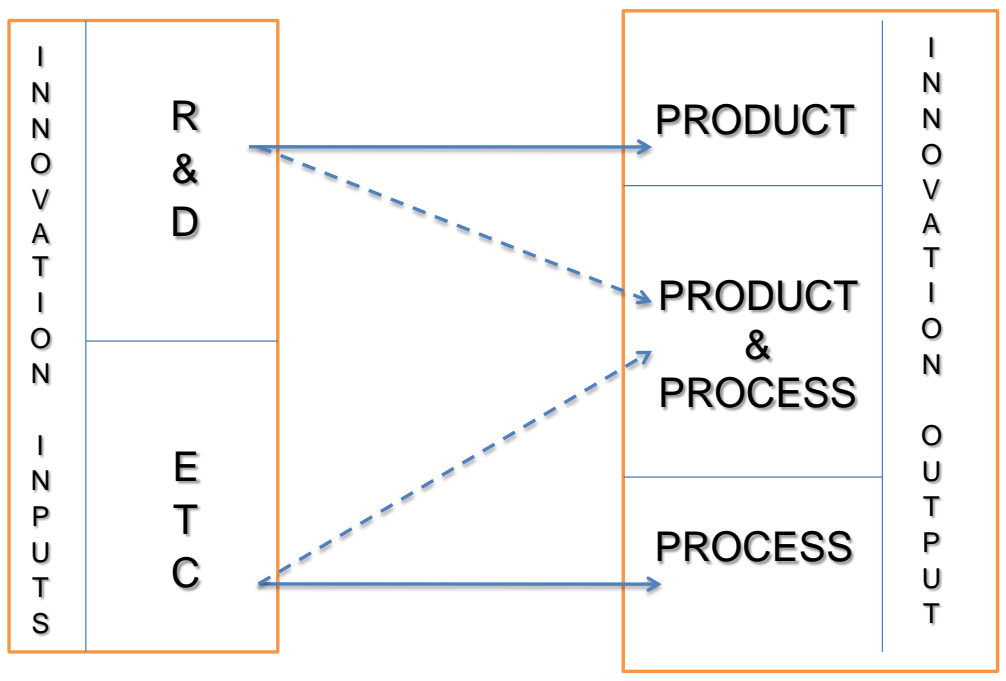

2) As discussed in Section 2, the final employment impact of innovation depends on institutional mechanisms, which can be very different at the micro, meso, and macro levels and can vary in different economic contexts, such as in different countries or in different sectors within the same country. For instance, a different degree of enforcement in the intellectual property rights (IPRs) can induce a different balance in the distribution between R\&D and ETC, and consequently can imply different employment outcomes. ${ }^{6}$

3) It is difficult to distinguish the final impact of innovation on employment, since the latter is influenced by many other factors: namely, the macroeconomic and cyclical conditions, the labor market dynamics, the trends in working time and so on.

The macroeconomic empirical analyses of the relationship between innovation and employment are largely affected by the three methodological problems discussed above.

\footnotetext{
${ }^{6}$ In the DCs, weak IPRs enforcement may induce under investment in R\&D and patentable activities; however, very strict IPRs regulations can hinder imitation and diffusion of product innovation among DCs' domestic firms.
} 
While empirical analyses are attractive, since they can take into account all the direct and indirect effects of innovation (see previous section), they are often severely constrained by the difficulty to find a proper aggregate proxy of technological change and by the fact that the final employment national trend is codetermined by overwhelming institutional and macroeconomic determinants that are difficult to control for. Although to a lesser extent, these considerations also apply when empirical analysis is carried out at the sectoral level. Moreover, either a negative or a positive bias sectoral analysis can affect the observation according to point of view (for instance, it is more likely to find an overall labor-saving effect in manufacturing sectors, while in services job creation is more easily detectable--see Section 3.1).

In this context, microeconometric studies have the great advantage to allow a direct and precise firm level mapping of innovation variables, both in terms of inputs and outputs (see Figure 4). Indeed, only firm-level data can account for R\&D expenditures, capital formation, and product and process innovation and directly relate them to the firm's employment trend. In other words, only the microeconometric empirical analysis can grasp the very nature of firms' innovative activities and throw some light on the actual ways that new products may generate new jobs, and labor-saving process innovation may destroy old ones. Moreover, shifting the analysis to the firm level makes it possible to avoid those important composition and confounding effects that affect the sectoral and aggregate studies (see the discussion above). ${ }^{7}$

Obviously, the need for the microeconometric analysis should also take into account important limitations of firm-level data. First, the microeconomic approach cannot take fully into account the indirect compensation effects (see Section 2), which operate not only at the firm level, but also through intersectoral linkages and aggregate dynamics. Second, a possible shortcoming of this kind of analysis consists in a "positive bias," which tends to underline the positive employment consequences of innovation. In fact, once the empirical analysis is developed at the level of the single firm, innovative firms tend to be characterized by better employment performances, since they gain market shares because of innovation. Even when the innovation is labor-saving, microeconomic analyses generally show a positive link between technology and employment, since they do not consider the important effect on the

\footnotetext{
${ }^{7}$ The aggregate and sectoral studies based on panel data often include sector and/or firm fixed effects, in order to control for unobserved heterogeneity; however, although necessary, these controls do not fully give account of those firms' characteristics, which can be crucial in affecting the relationship between innovation and employment.
} 
rivals, which are crowded out by the innovative firms (this is the so-called "business stealing" effect; see Section 3.3 below).

Keeping these methodological remarks in mind, now attention can be turned to the single levels of the empirical analysis of the relationship between technology and employment; consistently with what discussed so far, the macroeconomic and the sectoral studies will be briefly surveyed, while a more detailed attention will be devoted to the microeconometric literature.

\subsection{Aggregate Empirical Evidence}

As far as the aggregate empirical studies are concerned, macroeconometric studies have tried to test the validity of the compensation mechanisms (see Section 2) within a partial or general equilibrium framework. For instance, Sinclair (1981) puts forward a macro IS/LM scheme and concludes that positive employment compensation can occur if the demand elasticity and the elasticity of factor substitution are sufficiently high. Using estimates based on U.S. data, the author finds strong evidence supporting the mechanism "via decrease in wages" but not the mechanisms "via decrease in prices."

Layard and Nickell (1985) derive a demand for labor in a quasi-general equilibrium framework and state that the crucial parameter was the elasticity of the demand for labor in response to a variation in the ratio between real wages and labor productivity; in fact, technical change increases labor productivity and-given an adequate elasticityproportionally the demand for labor and this can be enough to fully compensate initial job losses. Using data for the UK economy, the authors estimate an elasticity coefficient equal to 0.9 and this was sufficient - in their opinion — to rule out technical change from the possible causes of British unemployment. ${ }^{8}$

Using a similar approach, Nickell and Kong (1989) focus on the operating of the compensation mechanism "via decrease in prices" in nine UK two-digit industries. Putting forward a price equation where cost-saving effects of labor-saving technologies were fully transferred into decreasing prices, the authors find that in seven sectors out of nine, a sufficiently high demand elasticity implied an overall positive impact of technical change on employment.

\footnotetext{
${ }^{8}$ See Vivarelli and Pianta (2000) for an extensive critical discussion about the role of technology and the role of labor market flexibility in determining employment performance.
} 
Through a simultaneous equations model over the period 1960-1988, Vivarelli (1995: chaps. 7, 8, and 9) tentatively represents and estimates the direct labor-saving effect of process innovation, the different compensation mechanisms, and the job-creating impact of product innovation. Running three stages least squares regressions using Italian and U.S. data, the author shows that the more effective compensation mechanism is that "via decrease in prices" in both countries, while other mechanisms are less important. In addition, the U.S. economy is more product-oriented (and so characterized by a positive relationship between technology and employment) than the Italian economy where different compensation mechanisms cannot counterbalance the labor-saving effect of prevailing process innovation.

Finally, Simonetti, Taylor and Vivarelli (2000) apply the same simultaneous equations macroeconomic model, running three stages least squares regressions using American, Italian, French, and Japanese data over the period 1965-1993. The authors show that the more effective compensation mechanisms were those "via decrease in prices" and "via increase in incomes" (especially in European countries until the mid1980s). The other mechanisms were less significant and conditional on the institutional structures of the different countries; for instance the "mechanism via decrease in wages" was relevant in the American flexible labor market. Finally, product innovation significantly showed its labor-intensive potentiality only in the technological leader country in the period, namely the United States.

\subsection{Sectoral Empirical Evidence}

The sectoral dimension is particularly important in investigating the overall employment impact of innovation; in particular, the compensation mechanism "via new product" (which in recent times often takes the form of a compensation "via new services") may accelerate the secular shift from manufacturing to services (see Evangelista and Perani, 1998; Evangelista and Savona, 1998).

On the other hand, in manufacturing, new technologies are characterized mainly by labor-saving ETC, only partially compensated by the market mechanisms discussed in Section 2. For instance, Clark (1983 and 1987) put forward a supply oriented vintage model investigating UK manufacturing. The author finds that the expansionary effect of innovative investments (Keynesian multiplier) was dominant until the mid-1960s, when the 
rationalizing effect (due to labor-saving ETC incorporated in investments and scrapping) started to overcome the expansionary one.

More recently, Pianta, Evangelista, and Perani (1996) find an overall positive relationship between growth in value added and growth in employment; nevertheless, especially in European countries, an important group of sectors appears to be characterized by a marked labor-saving trajectory (restructuring sectors), with growth in production and a fall in employment.

In another study based on Italian data, Vivarelli, Evangelista, and Pianta (1996) show that in Italian manufacturing, the relationship between productivity growth and employment appears to be negative and, in particular, that product and process innovation has opposite effects on the demand for labor, in line with what is discussed in the previous sections.

As already mentioned, the scenario may change if services sectors are taken into account. For instance - using standardized sectoral data derived from national CISs—Pianta (2000) and Antonucci and Pianta (2002) find an overall negative impact of innovation on employment in manufacturing industries across five European countries, while-in contrast - Evangelista (2000) and Evangelista and Savona (2002) find a positive employment effect of technological change in the most innovative and knowledge-intensive service sectors, while they find a negative one in the case of financial-related sectors and most traditional services like trade and transport.

Taking manufacturing and services jointly into account (using CIS cross-sectional sectoral data on relevant innovations for different European countries), Bogliacino and Pianta (2010) find a positive employment impact of product innovation (against a negative one of process innovation). Finally, Bogliacino and Vivarelli (2011)—running GMM-SYS panel estimations covering 25 manufacturing and service sectors for 15 European countries over the period 1996-2005—-find that R\&D expenditures—mainly fostering product innovation (see Figure 4)—show a job-creating effect.

\subsection{Microeconomic Empirical Evidence}

While the macroeconomic studies about the relationship between technology and employment seem to be confined to the 1980s and 1990s, the literature devoted to the microeconometric investigation of the issue has begun later, but it is nowadays flourishing. Starting from the earlier contributions, Entorf and Pohlmeier (1990) find a positive employment impact of product innovation-measured with a dummy — in a cross 
section of 2,276 West German firms in 1984. Smolny (1998) confirms the positive employment impact of product innovation in West German manufacturing by using a panel of 2,405 firms for the period 1980-1992.

Using the 1984 British Workplace Industrial Relations Survey, Machin and Wadhwani (1991) and Blanchflower, Millward, and Oswald (1991) find a negative raw correlation between Information and Communication Technologies (ICT) adoption and employment; however, once controlled for workplace characteristics and fixed effects, the same correlation turns out to be positive. In contrast with the previous studies, Brouwer, Kleinknecht, and Reijnen (1993)—using a cross-section of 859 Dutch manufacturing firms-discover an aggregate negative relationship between aggregate $R \& D$ expenditures and employment (while the opposite emerged when only product innovation was considered). By the same token, Zimmermann (1991)—using microdata from 16 German industries - concludes that technological change was one of the determinants of the employment decrease in Germany during the 1980s.

Although the employment impact of innovation is not the main object of Doms, Dunne, and Trotske (1997), the authors find that advanced manufacturing technologiesmeasured by a set of dummy variables — had implied higher employment growth in U.S. manufacturing plants over the period 1987-1991. More controversial results come from Klette and Førre (1998). The authors’ database comprises 4,333 Norwegian manufacturing plants over the period 1982-1992; in contrast with most of the other studies, they do not find any clear-cut positive relationship between net job creation and the R\&D intensity of the examined plants. Recent studies fully take the advantage of new available longitudinal datasets and applied more sophisticated panel data econometric methodologies. For example, Van Reenen (1997) match the London Stock Exchange database of manufacturing firms with the SPRU innovation database and obtain a panel of 598 firms over the period 1976-1982. Running GMM-DIF estimates, the author finds a positive employment impact of innovation and this result turns out to be robust after controlling for fixed effects, dynamics, and endogeneity. By the same token, Blanchflower and Burgess (1998) find a positive link between innovation (roughly measured with a dummy) and employment using two different panels of British and Australian establishments; their results are robust after controlling for sectoral fixed effects, size of firm, and union density.

Greenan and Guellec (2000) conduct an interesting panel analysis by using microdata from 15,186 French manufacturing firms over the 1986-1990 period. 
According to this study, innovating firms-defined according to the outcomes of an innovation survey_create more jobs than non-innovating ones, but the reverse is true at the sectoral level, where the overall effect is negative and only product innovation is jobcreating. Interestingly enough, the opposite employment impact of innovation at the firm and sectoral level may be due to the "business stealing effect" discussed above. ${ }^{9}$ However, even when taking the business stealing effect into account, ${ }^{10}$ Piva and Vivarelli (2004 and 2005) find evidence in favor of a positive effect of innovation on employment at the firm level. In particular-applying a GMM-SYS methodology to a longitudinal dataset of 575 Italian manufacturing firms over the period 1992-1997—-the authors provide evidence of a significant, although small in magnitude, positive link between firm's gross innovative investment and employment.

Using firm level data (obtained from the third wave of the Community Innovation Survey, CIS) from four European countries (Germany, France, UK, and Spain), Harrison et al. (2008) put forward a testable model_-based on Peters (2004)—able to distinguish the relative employment impact of process and product innovation (discrete variables). The authors conclude that process innovation tends to displace employment, while product innovation is basically labor friendly. However, compensation mechanisms (see Section 1) are at work and in the service sectors are particularly effective through the increase in the demand for the new products. Hall, Lotti, and Mairesse (2008) apply a similar model to a panel of Italian manufacturing firms over the period 1995-2003, and find a positive employment contribution of product innovation and no evidence of employment displacement due to process innovation.

More recently, Lachenmaier and Rottmann (2011) put forward a dynamic employment equation including wages, gross value added, years, and industries controls and alternative proxies (dummies) of current and lagged product and process innovation. Their GMM-SYS estimates_-based on a very comprehensive dataset of German manufacturing firms over the period 1982-2002-show a significantly positive impact of different innovation measures on employment. Partially in contrast with previous contributions, the authors find a higher positive impact of process rather than product innovation. ${ }^{11}$

\footnotetext{
${ }^{9}$ In particular, a labor-saving process innovation may imply job creation in those firms that introduce the new process into the market so gaining market shares; however, once the innovation is diffused within the sector, the prevailing labor-saving effect emerges.

${ }^{10}$ That is controlling for lagged firms' employment and current sales.

${ }^{11}$ However, this result can be due to the discrete nature of the adopted measure of process and product innovation (dummy variables). Interestingly enough, once the authors restrict their attention to (important) product innovation which went along with patent applications, they found out a highly positive and significant employment effect.
} 
Previous literature rarely splits the empirical analysis according to firms' sectoral belonging. One of the exceptions is the contribution by Greenhalgh, Longland, and Bosworth. (2001), which develops fixed effects estimates based on a panel of UK firms over the period 1987-1994. Consistently with most of the other studies discussed herein, the authors find a positive-albeit modest-effect of R\&D expenditures on employment. However, once the data is analyzed according to firms' sectoral belonging, the positive impact of R\&D on employment turns out to be limited to the sole high-tech sectors. In contrast, once the sectors are split into high-tech and non-high-tech ones, Lachenmaier and Rottmann (2011) did not find any significant sectoral heterogeneity in the effects that innovation has on employment.

In a very recent study, Coad and Rao (2011) limit their focus on U.S. high-tech manufacturing industries over the period 1963-2002 and investigate the impact of a composite innovativeness index (comprising information on both R\&D and patents) on employment. The main outcome of their quantile regressions is that innovation and employment are positively linked, and that innovation has a stronger impact for those firms that reveal the fastest employment growth.

Finally, Bogliacino, Piva, and Vivarelli (2011)—using a longitudinal database covering 677 European manufacturing and service firms over the period 1990-2008-find that a positive and significant employment impact of R\&D expenditures is detectable in services and high-tech manufacturing but not in the more traditional manufacturing sectors. On the whole-although previous microeconometric evidence is not fully conclusive about the possible employment impact of innovation-most recent panel investigations tend to support a positive link, especially when $R \& D$ and/or product innovation are adopted as proxies of technological change and when high-tech sectors are the focus.

\section{INNOVATION AND SKILLS}

Beyond the quantitative effect of new technologies on the number of employees, it is also interesting to single out and investigate the qualitative effect of technological change on the different categories of workers: the basic intuition here is that innovations are skill biased, therefore replacing tasks traditionally carried out by unskilled workers with new jobs demanding qualified workers. Indeed, the literature focusing on the complementary between technological change and skilled labor has put forward the so-called "skill biased technological change” (SBTC) hypothesis. Initially proposed by Griliches (1969) and 
Welch (1970), this hypothesis supports the view that new technologies-to be implemented effectively and efficiently-require suitable skills. A direct consequence of this hypothesis is that an insufficient number of qualified workers may be considered as a constraint, limiting the adoption and the diffusion of new technologies on the one hand and the pursuit of full employment on the other hand; this is the so called: "human resource constraint” (Amendola and Gaffard, 1988). Figure 5 illustrates this line of reasoning.

Figure 5: Technological Change, Skilled, and Unskilled Workers

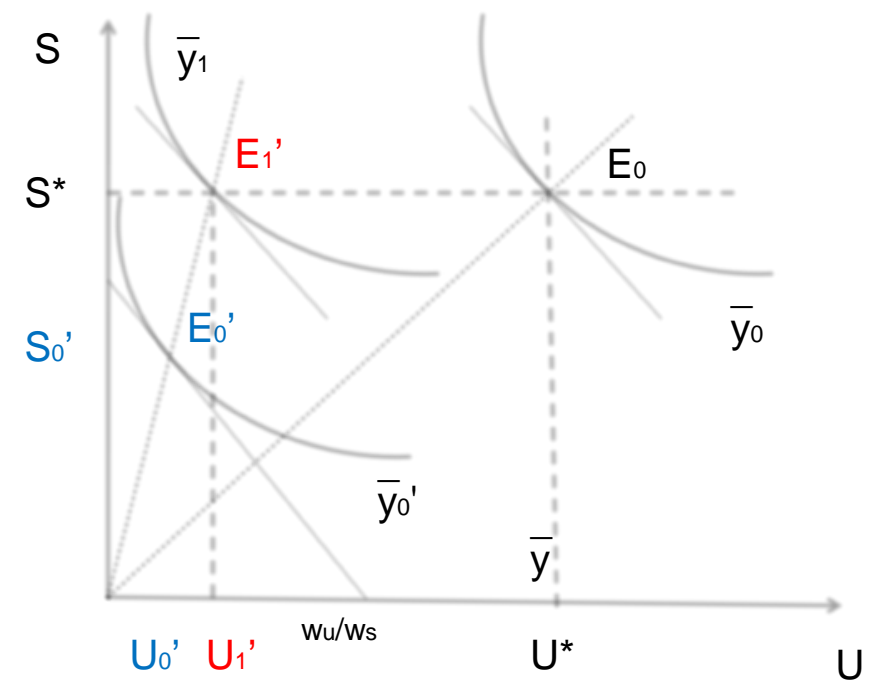

In Figure 5, technological change is related to the demand for skilled (S) and unskilled workers $(\mathrm{U})^{12}$ and the relevant factor prices are the wages for unskilled and skilled labor. Interestingly enough, from a theoretical point of view, the occurrence of a SBTC is often coupled with labor-saving process innovation (see previous sections), so generating the shift from the starting equilibrium $\mathrm{E}_{0}$ to $\mathrm{E}_{0}$ '. Therefore, if a SBTC process innovation occurs, the economy adjusts to the new equilibrium $E_{0}$; then, even if the compensation forces discussed in the previous sections fully display their efficacy in counterbalancing the initial job losses, the economy can only rise up to the new

\footnotetext{
${ }^{12}$ In contrast to Figures 1, 2, and 3, where the isoquants were related to capital and labor, as it is generally the case.
} 
equilibrium $E_{1}$ '. At the very best, the market compensation can assure full employment of the skilled labor, while the unskilled workers still suffer a dramatic decrease of their employment level from $\mathrm{U}^{*}$ to $\mathrm{U}_{1}$ '. In other words, in presence of a labor-saving and skillbiased process innovation, the scarcity of skilled labor can easily generate unemployment among the unskilled workers.

However, the literature on the skill-biased effect of technology is mainly empirical, starting from the consideration that during the last three decades-while the new ICT technologies were rapidly spreading - the main member countries of the Organisation for Economic Co-operation and Development (OECD) have shown a significant change, both in the composition of the labor force and in the wage shares, in favor of the skilled component of the labor force (see, for instance, Nickell and Bell, 1995; OECD, 1996; 1998) $)^{13}$.

In accordance with different institutional systems and different degrees of flexibility of the labor markets, economies have shown a dominant role either of the “employment effect” or the "wage effect.” In particular, an increase in wage differentials between skilled and unskilled have been registered in the United States (Autor, Katz, and Krueger, 1998) and in the United Kingdom (Haskel and Slaughter, 1998), while in the continental European countries, for example, France (Goux and Maurin, 2000), Germany (Abraham and Houseman, 1995), Italy (Casavola, Gavosto and Sestito, 1996), and Sweden (Hansson, 1997), the increase in wage differentials has been more limited. Symmetrically, in the European countries, there has been a greater impact on employment figures, with higher unemployment levels at least partly due to the reduction of the employment of the unskilled workers.

From a methodological point of view, the empirical test of the SBTC hypothesis is generally based on the estimation of a restricted function of total variable costs where capital and technology are assumed to be quasi fixed factors. Then, implementing the Shephard's lemma, either the wage bill shares of each class of workers or the employment shares are derived and estimated using a proxy for technology.

In what follows, a survey of the main empirical studies investigating the SBTC hypothesis is put forward, starting from articles devoted to the U.S. economy and then shifting to Canada, the UK, and continental Europe. The paper by Berman, Bound, and

\footnotetext{
${ }^{13}$ Traditionally, workers are split into two categories depending on the task: skilled and unskilled. The first category includes workers who do not undertake manual work (white collar) while the second includes manual workers (blue collar). An alternative typology is based on educational levels. The indicator based on tasks seems more suitable for verifying the presence of upskilling deriving from labor demand, meanwhile the indicator based on education partly reflects the continuous increase in the supply of skills.
} 
Griliches (1994) is considered seminal in starting the tradition of the empirical studies testing the SBTC hypothesis. In this paper, the authors analyze the dynamics of 450 U.S. manufacturing sectors during the 1980s. Their econometric analysis relates the shift in employment structure in favor of skilled workers to the investments in computers and R\&D. This result proves to be statistically significant in almost all sectors, supporting the SBTC hypothesis. Autor, Katz, and Krueger (1998) extend Berman’s study over a longer period, 1950-1990, also including nonmanufacturing sectors and confirming the complementary relationship between investment in computers and the skill structure.

Sectoral outcomes concerning the U.S. economy are also confirmed by studies using microdata. For instance, Dunne, Haltiwanger, and Troske (1997)—using U.S. manufacturing firms data from over the period 1972-1988-show a positive but not robust relation between 17 advanced industrial technologies and skilled labor; however, they find a positive and significant relationship between R\&D and skilled labor.

Doms, Dunne, and Troske (1997) follow a similar approach and show that the use of the most advanced industrial technologies leads to a greater utilization of workers with higher qualifications in a cross section analysis, even if, once the time dimension (19871992) is taken into account, the link between new technology and upskilling does not seem very significant; that is, the firms which introduce these innovations have betterskilled workers both before and after the introduction.

In a more recent work, Morrison Paul and Siegel (2001) try to assess simultaneously the impact of trade, technology, and outsourcing on shifts in labor demand using a dynamic cost function framework. Using an iterative 3SLS method and data on U.S. manufacturing sectors (1959-1989) and computing cost elasticity measures for four educational classes of workers, they show that technology has the strongest impact in favor of highly educated workers and simultaneously reduces the demand for workers without a college degree. They also find a strong interaction between trade and computers: trade induces computerization exacerbating the negative effects on the low skilled.

Betts (1997) — when studying the dynamics of the Canadian manufacturing economy between 1962 and 1986 using the Seemingly Unrelated Regression methodconfirms the fundamental role of the technological variable, measured just as a temporal trend, not only in causing replacement among the different productive inputs (WC, BC, energy, raw materials, and capital), but also in generating a significant skill biased effect in 11 out of 18 sectors. Gera, Gu, and Lin (2001) — when studying the dynamics of the Canadian manufacturing economy between 1981 and 1994-highlight the fundamental 
role of the technological variable, measured in four different dimensions, in generating a significant skill biased effect.

In terms of the empirical studies outside North America, results are generally consistent with the SBTC hypothesis, although sometimes less strikingly. Starting from the UK, Machin (1996) — using both firm-level data (1984-1990) and sector-level data (1979-1990) — shows a positive relation both between the use of computers and skilled labor in the case of the firms and between R\&D intensity, number of innovations produced, and number of innovations used, and skilled labor in the sector analysis. Machin's results are strengthened by a study by Haskel and Heden (1999) at firm level (during the 1980s), which confirms the positive relation between investment in computers and the presence of skilled labor.

As far as France is concerned, Mairesse, Greenan, and Topiol-Bensaïd (2001) obtain results similar to those of Machin (1996), using firm level data for 1986, 1990, and 1994, in a cross section where the technological variables are ICT capital and ICT workers; however, only the negative relation between ICT and less-qualified labor is robust in time-series. Moreover, Goux and Maurin (2000) show how an increased spread of new technology (both computers and new industrial technology) explains only 15 percent of the change in labor demand between 1970 and 1993 in their analysis of 34 French manufacturing sectors. Meanwhile, the upskilling would be driven by the movements of the internal demand towards skill-intensive productions.

For Germany, Falk and Seim (1999) study the impact of new technologies on more educated share of workers at the firm level (900 firms in 1994-1996) in service sectors. The firms devoting more resources in ICT employ more educated workers, even if the dimension of the relationship is small and strongly dependent on the specificity of sectors. But Falk (2001)—using a system of static and dynamic factor demand equations and considering three categories of workers-shows how the increase in office machinery and computer capital has accounted for at least 60 percent of expanding employment of university graduates in 35 manufacturing sectors for the period 1978-1994.

In Italy, Casavola, Gavosto, and Sestito (1996) use the Italian National Institute for Social Security (INPS) database, covering 36,000 Italian firms between 1986 and 1990, to study the effect of technological change on the labor demand and wages for skilled workers. They conclude that the wage difference between categories in Italy is lower than elsewhere, but that technological change has had a positive effect on the employment of skilled workers. However, using a sample of 412 manufacturing firms (1991-1997), Piva 
and Vivarelli (2001; 2002) do not find a clear link between R\&D and the skill bias. They show that the reorganization process of production has a significant impact on workers, especially at the work floor level, where the organizational change seems to drive the upskilling of the labor force. This result does not mean that Italian manufacturing sector, heavily characterized by the presence of SMEs, is immune to the SBTC; however, this probably does not take place mainly through internal channels-that is, in-house innovation resulting from $R \& D$ expenditure-but through organizational changes connected with the purchase and use of new technology. Piva, Santarelli, and Vivarelli (2005), estimating a SUR model for a sample of Italian manufacturing firms, confirm that upskilling is more a function of reorganizational strategy than a consequence of technological change alone. Moreover, some evidence of superadditive effects emerges, which is consistent with the notion that technology and organization jointly affect the demand for labor. Analyses based on microdata confined to a specific industry provide more heterogeneous results. For instance, Piva, Santarelli e Vivarelli (2006), using an original firm-level panel dataset in the Italian machinery industry, show that both skilled and unskilled workers are negatively affected by technological change. By the same token, Baccini and Cioni (2010) focus on the impact of new technologies on the skill composition in the Italian textile industry, showing that ETC negatively affect low-skilled workers in most cases, while only in rare cases high-skilled occupations are displaced by new machinery.

In Spain, Aguirregabiria and Alonso-Borrego (2001) use a panel of 1,080 manufacturing firms and test the relation between new technologies and upskilling using the GMM estimator for dynamic panels. Taking as technological variable a dummy on the introduction of "technological capital," the SBTC hypothesis is confirmed, while no significant effect emerges when referring to physical capital or R\&D expenditure. Luque (2005), using an unbalanced panel data of approximately 1,000 Spanish firms in the 19901998 period, show — through a decomposition methodology — that the raise in the skill mix comes mainly from surviving firms increasing their skill mixes in response to the retooling or upgrade in technology; moreover, firms belonging to high-tech sectors account for the majority of the increase in the skill mix.

Some authors go beyond the national level. Machin and Van Reenen (1998) set up a panel (at the manufacturing sector level for seven countries: Denmark, France, Germany, Japan, Sweden, the UK, and the United States) and show that the relative demand for skilled workers is positively linked to R\&D expenditure. The robustness of the results is 
confirmed both with reference to alternative econometric specifications and considering possible problems of endogeneity, that is, the presence of an inverse causal relation between technological innovation and skilled labor. ${ }^{14}$ On the whole, nowadays the evidence in favor of the skill-biased nature of new technologies is large, robust, and proven across different OECD countries, different economic sectors, and different types of innovation.

\section{A FOCUS ON THE DEVELOPING COUNTRIES}

While most of the empirical literature on the quantitative and qualitative employment impact of technological change is centered on the OECD countries, in recent times some attention has also been devoted to the specificities of the middle-income and low-income countries. The following sections investigate the relevant literature, starting from the relationship between technology and employment (Section 5.1) and then moving to the diffusion of SBTC to the DCs (Section 5.2).

\subsection{Innovation and Employment in the DCs}

Technological change in DCs is mainly imported and innovation is inherently connected with trade, foreign direct investment (FDI), and consequent international technologic transfer (see Acemoglu, 2003; Piva, 2003; Keller, 2004). Based on Figure 4, presented earlier herein, the DCs (especially low-income DCs) display a very limited capacity either in terms of in-house corporate $\mathrm{R} \& \mathrm{D}$ by the domestic firms or in terms of public investment in R\&D. However, new technologies are imported through licenses and especially through the importation of intermediate and capital goods from richer countries. This means that the dominant form of technological change within the DCs is the ETC contained in the capital goods (in primis machinery) imported from the developed economies. $^{15}$

Even though these imported technologies are not always the most updated, they are far more advanced than those traditionally adopted by local firms in most DCs. In other

\footnotetext{
${ }^{14}$ The possible problem of endogeneity is based on the consideration that only the firms that already have skilled workers see the potential for innovative investment. In the study by Machin and Van Reenen (1998),, the robustness control was successfully carried out by instrumenting the R\&D expenditure technological variable with government expenditure in R\&D, a variable which is not correlated with the error term (see also Piva and Vivarelli, 2009)

${ }^{15}$ That is why in many empirical studies on DCs the assumed explanatory variable for innovation is the total innovative expenditure rather than simply R\&D (see for example Crespi and Zuniga, 2010).
} 
words, without necessarily assuming that advanced economies transfer their "best" technologies to the DCs, it is quite reasonable to expect that transferred technologies are relatively more updated than those in use domestically, which are generally characterized by a lower capital intensity. In more detail, trade and FDI can imply a substantial upgrading in terms of technology in the opening of DCs through different channels. On the one hand, a DC can implement ETC by importing “mature” machineries (including secondhand capital goods—see Barba Navaretti, Solaga, and Takacs, 1998) from more industrialized countries. On the other, a lagging DC can enjoy the "latecomer" benefit of having immediate access to a relatively new technology (see Perkins and Neumayer, 2005). ${ }^{16}$ Moreover, in addition to a direct effect through ETC, imports and FDI inflows may generate technological spillovers in favor of the domestic firms, which can absorb the new imported technologies through labor mobility, input-output relationships, and reverse engineering (see Coe and Helpman, 1995; Coe, Helpman, and Homaister, 1997). Finally, technological catch-up may be induced by exporting to richer countries both through replacing outdated technologies in the exporting sectors and through the development of entirely new businesses characterized by process and product innovation addressed to satisfy a more sophisticated demand coming from the industrialized countries.

Other empirical literature investigates how import flows can in fact contribute to the international transfer of new technology to local firms in DCs. For instance, Coe and Helpman (1995) analyze a sample of OECD countries and find that foreign knowledge embodied in traded goods has a statistically significant positive impact on aggregate total factor productivity (TFP) in importing countries. Coe, Helpman, and Homaister (1997) extend the analysis to DCs and show that imports of intermediate goods raise the TFP in DCs as well. By focusing on DCs alone, Mayer (2000) restricts the definition of import shares by considering only machinery and finds that in this case, the impact of foreign R\&D is much greater. Schiff and Wang (2006) underline how trade-related technology diffusion can occur through an increase in a country's level of exposure to that technology through trade (quantity) or through an increase in the knowledge content of that trade (quality). Other studies use firm level database to examine imports as a mechanism for technological transfer and find that imports can in fact improve firm technological capabilities (see for example, Blalock and Veloso, 2007).

\footnotetext{
${ }^{16}$ An example being the diffusion of mobile telecommunications in Sub-Saharian Africa in countries where the traditional telephone networks are limited to few urban areas.
} 
With regard to the export channel, breaking into foreign markets allows firms located in the DCs to acquire knowledge of international best practices. On the one hand, foreign buyers often provide their suppliers with technical assistance and product design in order to improve the quality of imported goods, and they may transmit the tacit knowledge acquired from other suppliers located in advanced countries to their suppliers located in DCs (Epifani, 2003). For instance, Yeaple (2005) shows that increased export opportunities make the adoption of new technologies profitable for more firms. Bustos (2005) builds a model upon the works of Yeaple (2005), while Melitz (2003) argues that trade liberalization reduces variable export costs and makes the adoption of new technologies more likely. All in all, technology transfer in favor of DCs involves productivity gains, which can be harmful to the local DC's employment levels. In particular, the dominant role of the imported ETC implying labor-saving process innovation can drastically decrease the domestic demand for labor (see Figure 4).

Specifically, as discussed by Taylor (2004), the final employment outcome depends on the balance between labor productivity gains and output growth induced by domestic demand, trade, and FDI. ${ }^{17}$ Therefore, in determining the final employment outcome, the price and income compensation mechanisms discussed in Section 2 are obviously crucial in the DCs as well (see Hall and Heffernan, 1985). Yet, different there is also evidence to support the view that “compensation” of labor-saving effects of new technologies may be more difficult in developing countries rather than in developed ones.

First, as already mentioned, $R \& D$ based product innovation is much more rare in DCs (and almost absent in low-income DCs) and this makes this labor-friendly component of technological change rather ineffective in determining the final outcome in terms of local employment. ${ }^{18}$ Second, price compensation mechanisms (via "decrease in prices" and “decrease in wages," as discussed in Section 2) can be severely hindered by a low degree of competition of the local goods and labor markets. Third, income compensation mechanisms (via "new investments" and "new incomes") can be slowed down by a tendency to invest abroad and to spend additional income in luxury goods imported by richer countries. Finally, the ultimate effect in terms of growth and employment is mediated by the "absorptive capacity” of a given DC (see Abramovitz, 1986; Lall, 2004).

\footnotetext{
${ }^{17}$ In his study, Taylor (2004) finds that in 7 out of 11 DCs, output per capita in the traded goods sector grew less rapidly than labor productivity, which implies job losses.

${ }^{18}$ DCs might also use other mechanisms to access product innovations developed abroad, such as licensing or reverse engineering. However, to successfully carry out these passive forms of technological upgrading, they still need a sufficient level of absorptive capacity (see next section).
} 
In other words, only those DCs that enjoy a sufficient level of endogenous R\&D and innovation capabilities would be able to fully develop the growth and employment potentialities of the new technologies, with particular reference to the labor-friendly product innovations. Unfortunately, this is not the case for many low-income countries where the lack of absorptive capacity by domestic firms severely limits the implementation of the new technologies developed abroad, either through import or through spillovers from FDI inflows.

\subsection{Skill-biased Technological Change in the DCs}

From a theoretical point of view, in the developed world both trade liberalization (through the Heckscher-Ohlin theorem and in its Stolper-Samuelson corollary, from now on HOSS mechanism) and technological change could be responsible for the observed pattern of increased relative demand for skilled labor (see Section 4). In contrast, in DCs the two processes are supposed to have opposite effects (for an extensive analysis, see Lee and Vivarelli, 2004, 2006a; 2006b). On the one hand—as broadly discussed in Section 4-new technologies shift the labor demand in favor of more skilled workers; on the other hand, the HOSS mechanism predicts that a DC trading with skill-abundant developed economies should specialize in the production of unskilled-labor-intensive goods and therefore experience a relative increase in the demand for unskilled labor.

However, if the HOSS assumption of homogeneous production functions and identical technologies between countries is relaxed, then international openness may facilitate technology diffusion from industrialized to developing countries (see Section 5.1), implying that trade and technological change are complementary rather than alternative mechanisms. The idea is that trade liberalization accelerates the flows of imported ETC (in machineries, intermediate inputs, and components) to DCs, inducing an adaptation to the modern skill-intensive technologies currently used in more advanced countries, and resulting in an increase in the demand for skilled workers (for a more extensive analysis, see Vivarelli, 2004).

Robbins (1996; 2003) and Robbins and Gindling (1999) call the effect of inflowing technology resulting from trade liberalization the "skill-enhancing trade (SET) hypothesis." Their idea is that trade accelerates the flows of physical capital (and embodied technology) to the South, inducing rapid adaptation to the modern skill- 
intensive technologies currently used in the North. The resulting increased demand for skilled labor may then lead to a widening of wage and income dispersion in DCs.

In terms of the empirical literature, a large number of works have documented the relevance of the SBTC hypothesis for advanced countries (see Section 4), while evidence for developing countries is less abundant. However, Berman and Machin (2000; 2004) find that "within-industry" skill upgrading in middle-income countries was due to the adoption of the same kinds of skill-biased technologies that had permeated into industries in the developed world, implying that SBTC had been transferred rapidly from the developed world to middle-income countries, and emphasizing the pervasive nature of SBTC.

Meschi and Vivarelli (2009) analyze the impact of trade openness and technology transfer on income distribution in a panel of DCs. Once they had disaggregate trade flows according to their areas of origin/destination, they find a significant inequality-enhancing effect in middle-income DCs due to trade with more advanced countries, possibly related to technological transfer and skill-enhancing trade. Almeida (2009) reaches very similar conclusions using firm-level data for East Asia. By the same token, Conte and Vivarelli (2010), using a direct measure of embodied technological transfer, find that imported skillbiased technological change is one of the determinants of the increase in the relative demand for skilled workers in DCs.

While the empirical cross-country literature supports the view that SBTC is rapidly diffusing into DCs (at least the middle-income ones), the evidence from country-specific studies is mixed. Hanson and Harrison (1999), using data on Mexican manufacturing plants, find that firms receiving FDI acquire technology through licensing agreements or imported materials, and tend to hire more skilled workers. Feenstra and Hanson (1997) reach a similar conclusion. Using data on Mexican industries, they find that FDI were positively correlated with the relative demand for skilled labor. Similarly, Fajnzylber and Fernandes (2009) find that increased levels of international integration are associated with an increased demand for skilled labor in a cross-section of Brazilian firms. In contrast, Pavcnik (2003) investigate the causes of skill upgrading in Chilean plants during the 1980s and fails to find a significant relationship between measures of adoption of foreign technology and the relative demand for skilled workers when controlling for unobserved plant heterogeneity. However, Fuentes and Gilchrist (2005) extend Pavcnik's analysis over an additional nine-year time span to cover the period 1979-1995 and find a robust 
association between the demand for skilled workers and the adoption of new foreign technologies.

Görg and Strobl (2002) analyze a panel of manufacturing firms in Ghana over the 1990s; their estimates revealed that while the purchase of foreign machinery for technological purposes significantly raises the relative demand for skilled labor, a greater participation in world markets via exporting activities does not have any effect. Giovanetti and Menezes-Filho (2006) analyze the evolution of skilled employment in Brazil over the 1990-1998 period. First, they detect an increase in the skilled labor share; this increase is entirely due to the "within-industry" effect, while the "between-industries" effect was negative, in line with the HOSS predictions. Then, inspired by Machin and Van Reenen (1998), they calculate an econometric equation to test the SET hypothesis. Their variable is input tariffs, the hypothesis being that the reduction of input tariffs should have induced the importation of technologically-advanced inputs, in turn raising the demand for skilled labor. Consistent with their hypothesis, they find that tariffs are negatively related to skillupgrading, and that this effect is stronger in those sectors that use inputs more complementary to skills.

Other papers instead underline the skill-enhancing effects of exporting activity, which makes the adoption of new technologies profitable for more firms (Yeaple, 2005), induces quality upgrading (Verhoogen, 2008; Fajnzylber and Fernandes, 2009), and offers opportunities to acquire knowledge of international best practice (the so-called learning-by-exporting hypothesis, see Epifani, 2003; Bigsten et al., 2004). Finally, at least for middle-income DCs, together with imported technologies and exports, domestic R\&D and innovation may play a relevant role, as is the case for the most advanced countries. For instance, Meschi, Taymaz, and Vivarelli (2011)—running GMM-SYS estimates on panel data covering 17,462 Turkish manufacturing over the period 1980-2001—show that SET was an important factor in explaining the rise of the skilled labor cost share, together with domestic R\&D. By the same token, Araújo, Bogliacino, and Vivarelli (2011)—using a panel database of Brazilian manufacturing firms over the period 1997-2005-also find evidence in support of both the role of SET and domestic technology in determining the skill-upgrading trend of the Brazilian manufacturing labor force. 


\section{CONCLUSIONS}

As preliminary conclusions have been already discussed in previous sections, this section briefly summarizes the main findings of this study.

- In terms of quantitative effects, process innovation tends to have a labor-saving impact, while product innovation exhibit a labor-friendly nature.

- According to the classical "compensation theory," market forces should assure a complete compensation of the initial labor-saving impact of process innovations; however, in Section 2 discusses different possible hindrances to the various compensation mechanisms, reaching the general conclusion that compensation may be only partial, depending on the particular institutional setting and on the specific values of crucial parameters, such as demand elasticity, degree of competition, capital-labor substitution, demand expectations, and so on.

- Since economic theory does not have a clear-cut answer about the employment effect of innovation, there is a strong need for aggregate, sectoral, and microeconomic empirical analyses able to take into account the different forms of technological change, their direct effects on labor, the various compensation mechanisms, and the possible hindrances to these mechanisms.

- In particular, microeconometric studies have the great advantage to allow a direct and precise firm's level mapping of innovation variables, both in terms of inputs and outputs. Indeed, only firm’s level data can account for R\&D expenditures, capital formation, and product and process innovation and directly relate them to firm's employment trends.

- In general, the microeconometric literature, and particularly the most recent panel data analyses, tend to support a positive link between technology and employment, especially when $R \& D$ and/or product innovation are adopted as proxies of technological change and when high-tech sectors are the focus.

- Beyond the quantitative effect of new technologies on the number of employees, it is also important to investigate the qualitative effect of technological change in terms of its possible skill bias. Nowadays, the evidence in favor of the skill-biased nature of new technologies is large, robust, and proven across different OECD countries, different economic sectors and different types of innovation. 
- Turning the attention to the DCs, technological change is mainly imported and innovation is more determined by trade, FDI, and consequent technology transfer, rather than by domestic private and public R\&D expenditures.

- In this respect, the paucity of R\&D-based product innovation and the presence of institutional hindrances to the "compensation" mechanisms render a net laborsaving impact of technology more likely in the DCs rather than in developed countries.

- As far as SBTC in DCs is concerned, a growing literature shows that SBTC has been transferred rapidly from the developed world to middle-income countries, while this is not still so obvious for low-income DCs, characterized by a lower absorptive capacity.

- A recent empirical literature shows that both the SET and domestic technology are crucial factors in determining the revealed skill-upgrading trend in middle-income DCs. 


\section{REFERENCES}

Abowd, J.M., J. Haltiwanger, J. Lane, K.L. McKinney, K. and Sandusk. 2007. "Technology and the Demand for Skill: An Analysis of Within and Between Firm Differences.” IZA Discussion Paper, 2707. Bon: IZA.

Abraham, K., and S. Houseman. 1995. "Earnings Inequality in Germany.” In R.B. Freeman and L.F. Katz (eds), Differences and Changes in Wage Structures. Chicago: NBER, University of Chicago Press: 371-403.

Abramovitz, M. 1986. “Catching-up, Forging Ahead and Falling Behind.” Journal of Economic History, 46: 385-406.

Acemoglu, D. 2003. Patterns of Skill Premia. Review of Economic Studies, 70: 199-230.

Aguirregabiria, V., and C. Alonso-Borrego. 2001. "Employment Occupational Structure, Technological Innovation, and Reorganization of Production.” Labor Economics, 8: 43-73.

Almeida, R. 2009. "Openness and Technological Innovation in East Asia: Have They Increased the Demand for Skills?” IZA Discussion Papers, 4474. Bonn, Germany: IZA.

Amendola, M., and J.L. Gaffard. 1988. The Innovative Choice. Oxford: Basil Blackwell.

Antonucci, T., and M. Pianta. 2002. "Employment Effects of Product and Process Innovation in Europe.” International Review of Applied Economics, 16: 295-307.

Appelbaum, E., and R. Schettkat. 1995. "Employment and Productivity in Industrialized Economies.” International Labor Review, 134: 605-23.

Araújo, B.C., Bogliacino, F., Vivarelli, M., 2011. “Technology, Trade and Skills in Brazil: Some Evidence from Microdata.” Revista CEPAL/CEPAL Review, forthcoming.

Arrighetti, A., and M. Vivarelli. 1999. "The Role of Innovation in the Postentry Performance of New Small Firms: Evidence from Italy.” Southern Economic Journal, 65, 927-39.

Autor, D., L. Katz, and A. Krueger. 1998. "Computing Inequality: Have Computers Changed the Labor Market?” Quarterly Journal of Economics, 113, 1169-1214.

Baccini, A., and M. Cioni. 2010. "Is Technological Change Really Skill-biased: Evidence from the Introduction of ICT in the Italian Textile Industry (1980-2000).” New Technology, Work and Employment, 25: 80-93.

Barba Navaretti, G., I. Solaga, and W. Takacs. 1998. "When Vintage Technology Makes Sense: Matching Imports to Skills.” World Bank Working Paper 1923. Washington, DC: World Bank.

Berman, E., and S. Machin. 2000. "Skill-biased Technology Transfer Around the World.” Oxford Review of Economic Policy, 16: 12-22.

—. 2004. "Globalization, Skill-biased Technological Change and Labor Demand”. In E. Lee and M. Vivarelli (eds), Understanding Globalization, Employment and Poverty Reduction. New York: Palgrave Macmillan.

Berman, E., J. Bound, and Z. Griliches. 1994. "Changes in the Demand for Skilled Labor within U.S. Manufacturing Industries: Evidence from the Annual Survey of Manufacturing.” Quarterly Journal of Economics, 109: 367-97. 
Betts J. 1997. The Skill Bias of Technological Change in Canadian Manufacturing Industries. Review of Economics and Statistics, 79: 146-50.

Bigsten, A., P. Collier, S. Dercon, M. Fafchamps, et al. 2004. "Do African Manufacturing Firms Learn from Exporting?” The Journal of Development Studies, 40: 1151-41.

Blalock, G. and F.M. Veloso. 2007. "Imports, Productivity Growth, and Supply Chain Learning.” World Development, 35: 1134-51.

Blanchflower, D., and S.M. Burgess. 1998. "New Technology and Jobs: Comparative Evidence from a Two-Country Study.”Economics of Innovation and New Technology, 5: 109-38.

Blanchflower, D., N. Millward, and A. Oswald. 1991. "Unionisation and Employment Behaviour.” Economic Journal, 101: 815-34.

Bloom, N., and J. Van Reenen. 2010. "Why Do Management Practices Differ across Firms and Countries?” Journal of Economic Perspectives, 24: 203-24.

Bogliacino, F., and M. Pianta. 2010. "Innovation and Employment: A Reinvestigation Using Revised Pavitt Classes.” Research Policy, 39: 799-809.

Bogliacino, F., and M. Vivarelli. 2011. "The Job Creation Effect of R\&D Expenditures.” IZA Discussion Papers, 4728. Bonn, Germany: IZA.

Bogliacino, F., M. Piva, and M. Vivarelli. 2011. "R\&D and Employment: Some Evidence from European Microdata.” IZA Discussion Papers, 5908. Bonn, Germany: IZA.

Boyer, R. 1988a. "New Technologies and Employment in the 1980s: From Science and Technology to Macroeconomic Modeling." In J.A. Kregel, E. Matzner and A. Roncaglia (eds), Barriers to Full Employment. London: Macmillan.

- 1988b. "Assessing the Impact of R\&D on Employment: Puzzle or Consensus?" Paper presented at the International Conference on New Technology: Its Impacts on Labor Markets and the Employment System, December 5-7, Berlin.

. 1988c. "Technical Change and the Theory of Regulation." In G. Dosi, C. Freeman, R.R. Nelson, G. Silverberg and L. Soete (eds), Technical Change and the Economic Theory. London: Pinter.

1988d. "Formalizing Growth Regimes.” In G. Dosi, C. Freeman, R.R. Nelson, G. Silverberg and L. Soete (eds), Technical Change and the Economic Theory. London: Pinter.

1990. "The Capital Labor Relations in OECD Countries: From the Fordist "Golden Age” to Contrasted National Trajectories.” Working paper CEPREMAP, 9020. Paris, France: Centre pour la Recherche Economique et ses Applications.

Bresnahan, T.F., E. Brynjolfsson, and L.M. Hitt. 2002. "Information Technology, Workplace Organization and the Demand for Skilled Labor: Firm-level Evidence.” Quarterly Journal of Economics, 117: 339-76.

Brouwer, E., A., Kleinknecht, and J.O.N. Reijnen. 1993. "Employment Growth and Innovation at the Firm Level: An Empirical Study." Journal of Evolutionary Economics, 3: 153-59.

Bustos, P. 2005. "The Impact of Trade on Technology and Skill Upgrading: Evidence from Argentina.” Barcelona: CREI and Universitat Pompeu Fabra. Unpublished. 
Caroli, E., N. Greenan, and G. Guellec. 2001. "Organizational Change and Skill Accumulation.” Industrial and Corporate Change, 10: 479-504.

Caroli, E., and J. Van Reenen. 2001. "Skill Biased Organizational Change? Evidence from a Panel of British and French Establishments.” Quarterly Journal of Economics, 116: 1449-92.

Casavola, P., A. Gavosto, and P. Sestito. 1996. "Technical Progress and Wage Dispersion in Italy: Evidence from Firms' Data.” Annales d'Economie et de Statistique, 41/42, 387-412.

Cefis, E. and O. Marsili. 2005. "A Matter of Life and Death: Innovation and Firm Survival.” Industrial and Corporate Change, 14: 1167-92.

35: $626-41$.

Clark, J.B. 1907. Essentials of Economic Theory. New York: Macmillan.

Clark, J. 1983. “Employment Projections and Technological Change.” In D.L. Bosworth (ed), The Employment Consequences of Technical Change. London: Macmillan.

Clark, J. 1987. “A Vintage-Capital Simulation Model.” In C. Freeman and L. Soete (eds), Technical Change and Full Employment. Oxford: Basil Blackwell.

Coad, A., and R. Rao. 2011. "The Firm-level Employment Effects of Innovations in HighTech U.S. Manufacturing Industries.” Journal of Evolutionary Economics, 21: 25583.

Coe, D.T., and E. Helpman. 1995. International R\&D Spillovers. European Economic Review, 39: 859-87.

Coe, D.T., E. Helpman, and A. Homaister. 1997. "North-South Spillovers.” Economic Journal, 107: 134-49.

Conte, A., and M. Vivarelli. 2005. "One or Many Knowledge Production Functions? Mapping Innovative Activity Using Microdata.” IZA Discussion Paper 1878. Bonn, Germany: IZA.

Conte, A., Vivarelli, M., 2010. "Imported Skill Biased Technological Change in Developing Countries.” Developing Economies, 49: 36-65.

Crespi, G., and P. Zuniga. 2010. "Innovation and Productivity: Evidence from Six Latin American Countries.” RES Working Papers 4690. Washington, DC: Inter-American Development Bank.

Dobbs, I.M., M.B. Hill, and M. Waterson. 1987. "Industrial Structure and the Employment Consequences of Technical Change.” Oxford Economic Papers, 39: 55267.

Doms, M., T. Dunne, and K. Troske. 1997. "Workers, Wages, and Technology." Quarterly Journal of Economics, 112, 253-89.

Dosi, G. 1982. “Technological Paradigms and Technological Trajectories.” Research Policy, 11: 147-63.

- 1988. "Source, Procedure and Microeconomic Effects of Innovation." Journal of Economic Literature, 26: 1120-71.

Douglas, P.H. 1930. “Technological Unemployment.” American Federationist, 37: 92350 . 
Dunne, M., Haltiwanger, J., Troske, K., 1997. Technology and jobs: Secular changes and cyclical dynamics. The Carnegie-Rochester Conference Series on Public Policy, 46, 107-178.

Edquist, C., L. Hommen, and M. McKelvey. 2001. Innovation and Employment: Product Versus Process Innovation. Cheltenham: Elgar.

Entorf, H., and W. Pohlmeier. 1990. Employment, Innovation and Export Activities. In J.P. Florens, M. Ivaldi, J.J. Laffont and F. Laisney (eds), Microeconometrics: Surveys and Applications. London: Basil Blackwell.

Epifani, P., 2003. “Trade Lliberalization, Firm Performance, and Labor Market Outcomes in the Developing World: What can we Learn from Micro-level Data?” Policy Research Working Paper Series, 3063. Washington, DC: World Bank.

Evangelista, R. 2000. "Innovation and Employment in Services.” In M. Vivarelli and M. Pianta (eds), The Employment Impact of Innovation: Evidence and Policy. London: Routledge, 121-48.

Evangelista, R., and G. Perani. 1998. "Innovation and Employment in Services: Results from the Italian Innovation Survey.” Paper presented at the EAEPE Conference, 5-8 November, Lisbon, Portugal.

Evangelista, R., and M. Savona. 1998. "Patterns of Innovation in Services. The Results of the Italian Innovation Survey." Paper Presented at the VIII Annual RESER Conference, 8-10 October, Berlin, Germany.

Evangelista, R., M. Savona. 2002. "The Impact of Innovation on Employment in Services: Evidence from Italy.” International Review of Applied Economics, 16, 309-18.

Fajnzylber, P., and A. Fernandes. 2009. "International Economic Activities and Skilled Labor Demand: Evidence from Brazil and China.” Applied Economics, 41, 563-77.

Falk, M. 2001. "The Impact of Office Machinery and Computer Capital on the Demand for Heterogeneous Labor.” ZEW Discussion Paper, 01-66. Mannheim, Germany: The Centre for European Economic Research.

Falk, M., and K. Seim. 1999. "The Impact of Information Technology on High-skilled Labor in Services: Evidence from Firm Level Panel Data.” ZEW Discussion Paper, 99-58. Mannheim, Germany: The Centre for European Economic Research.

Feenstra, R.C., and G.H. Hanson. 1997. Foreign Direct Investment and Relative Wages: Evidence from Mexico's Maquiladoras. Journal of International Economics, 42: 37193.

Freeman, C., J. Clark, and L. Soete. 1982. Unemployment and Technical Innovation. London: Pinter.

Freeman, C., and L. Soete. (eds). 1987. Technical Change and Full Employment. Oxford: Basil Blackwell.

Freeman, C., and L. Soete. 1994. Work for All or Mass Unemployment? Computerised Technical Change into the Twenty-first Century. London-New York: Pinter.

Fuentes, O., and S. Gilchrist. 2005. "Trade Orientation and Labor Market Evolution: Evidence from Chilean Plant-level Data.” In J. Restrepo and A. Tokman (eds), Labor Markets and Institutions. Santiago: Central Bank of Chile. 
Gera, S., W. Gu, and Z. Lin. 2001. "Technology and the Demand for Skills: An Industrylevel Analysis. The Canadian Journal of Economics, 34: 132-48.

Giovanetti, B., and N. Menezes-Filho. 2006. "Trade Liberalization and Demand for Skilled Labor in Brazil.” Economia (Journal of LACEA), 7: 1-28.

Görg, H., and E. Strobl. 2002. "Relative Wages, Openness and Skill-Biased Technological Change.” IZA Discussion Papers, 596. Bonn, Germany: IZA.

Goux, D., and E. Maurin. 2000. "The Decline in Demand for Unskilled Labor: An Empirical Method and its Application to France. Review of Economics and Statistics, 82, 596-607.

Greenan, N. 2003. "Organisational Change, Technology, Employment and Skills: An Empirical Study of French Manufacturing.” Cambridge Journal of Economics, 27: 287-316.

Greenan, N., and D. Guellec. 2000. "Technological Innovation and Employment Reallocation.” Labor, 14: 547-90.

Greenhalg, C., M. Longland, and D. Bosworth. 2001. "Technological Activity and Employment in a Panel of UK Firms.” Scottish Journal of Political Economy, 48, 260-82.

Greenwood, J., Z. Hercowitz, and P. Krusell. 1997. "Long-run Implications of Investmentspecific Technological Change.” American Economic Review, 87, 342-62.

Griliches, Z. 1969. “Capital-skill Complementarity.” Review of Economics and Statistics, 51: 465-68.

Hall, P.H., and S.A. Heffernan. 1985. "More on the Employment Effects of Innovation. Journal of Development Economics, 17: 151-62.

Hall, B.H., F. Lotti, and J. Mairesse. 2008. "Employment, Innovation, and Productivity: Evidence from Italian Microdata.” Industrial and Corporate Change, 17: 813-39.

Hanson, G., and A. Harrison. 1999. “Trade and Wage Inequality in Mexico.” Industrial and Labor Relations Review, 52: 271-88.

Hansson, P. 1997. "Trade, Technology and Changes in Employment of Skilled Labor in Swedish Manufacturing.” In J. Fagerberg, P. Hansson, L. Lundberg and A. Melchior (eds), Technology and International Trade. Aldershot: Elgar, 200-16.

Harrison, R., J. Jaumandreu, J. Mairesse, and B. Peters. 2008. “Does Innovation Stimulate Employment? A Firm-level Analysis Using Comparable Microdata from Four European Countries.” NBER Working Papers, 14216. Cambridge MA: NBER.

Haskel, J., and Y. Heden. 1999. "Computers and the Demand for Skilled Labor: Industry and Establishment-level Evidence for the UK.” Economic Journal, 109: C68-C79.

Haskel, J., and M. Slaughter. 1998. "Does the Sector Bias of Skill Biased Technical Change Explain Changing Wage Inequality?” NBER Working Paper, 6565. Cambridge MA: NBER.

Heffernan, S.A., 1981. Technological Unemployment. Unpublished Ph.D. Thesis. Oxford: Oxford University.

Hercowitz, Z. 1998. “The 'Embodiment' Controversy: A Review Essay.” Journal of Monetary Economics, 41: 217-24.

Hicks, J.R. 1932. The Theory of Wages. London: Macmillan. 
Hicks, J.R. 1973. Capital and Time. Oxford: Oxford University Press

Hobsbawm, E.J. 1968. Industry and Empire: An Economic History of Britain Since 1750. Harmondsworth Middlesex: Penguin Books.

Hobsbawm, E.J., and G. Rudé. 1969. Captain Swing. London: London Reader’s Union.

Hulten, C.R. 1992. "Growth Accounting when Technical Change is Embodied in Capital.” American Economic Review, 82: 964-80.

Istat. 1997. Statistiche sull'Innovazione Tecnologica 1994-1996. Roma: Istat.

Katsoulacos, Y.S. 1984. "Product Innovation and Employment." European Economic Review, 26: 83-108.

Katsoulacos, Y.S. 1986. The Employment Effect of Technical Change. Brighton: Wheatsheaf.

Keller, W. 2004. “International Technology Diffusion.” Journal of Economic Literature, 42, 752-82.

Keynes, J.M. 1973. “The General Theory of Employment, Interest and Money.” In The Collected Writings of John Maynard Keynes. London: Macmillan. First edition 1936.

Klette, T.J., and S.E. Førre. 1998. "Innovation and Job Creation in a Small Open Economy: Evidence from Norwegian Manufacturing Plants 1982-92.” Economics of Innovation and New Technology, 5, 247-272.

Lachenmaier, S., and H. Rottmann. 2011. "Effects of Innovation on Employment: A Dynamic Panel Analysis. International Journal of Industrial Organization, 29, 21020.

Lall, S. 2004. “The Employment Impact of Globalization in Developing Countries.” In E. Lee and M. Vivarelli (eds), Understanding Globalization, Employment and Poverty Reduction. New York: Palgrave Macmillan.

Layard, R., and S. Nickell. 1985. "The Causes of British Unemployment.” National Institute Economic Review, 111: 62-85.

Layard, R., S. Nickell, and R. Jackman. 1991. Unemployment: Macroeconomic Performance and the Labor Market. Oxford: Oxford University Press.

Layard, R., S. Nickell, S., and R. Jackman. 1994. The Unemployment Crisis. Oxford: Oxford University Press.

Lee, E., and M. Vivarelli. 2004 (eds). Understanding Globalization, Employment and Poverty Reduction. New York: Palgrave Macmillan.

Lee, E., and M. Vivarelli. 2006a (eds). Globalization, Employment, and Income Distribution in Developing Countries. New York: Palgrave Macmillan.

_. 2006b "The Social Impact of Globalization in Developing Countries." International Labor Review, 145: 167-84.

Luque, A. 2005. "Skill Mix and Technology in Spain: Evidence from Firm-level Data. Documento de Trabajo, 0513. Madrid: Banco de Espana.

Machin, S. 1996. "Changes in the Relative Demand for Skills.” In A.L. Booth and D.J. Snower (eds), Acquiring Skills: Market Failures, Their Symptoms and Policy Responses. Cambridge: Cambridge University Press. 
Machin, S., and J. Van Reenen. 1998. "Technology and Changes in Skill Structure: Evidence from Seven OECD Countries.” Quarterly Journal of Economics, 113: 121544.

Machin, S., and S. Wadhwani. 1991. "The Effects of Unions on Organisational Change and Employment: Evidence from WIRS.” Economic Journal, 101: 324-30.

Mairesse, J., N. Greenan, and A. Topiol-Bensaïd. 2001. "Information Technology and Research and Development Impacts on Productivity and Skills: a Comparison on French Firm Level Data.” NBER Working Paper, 8075. Cambridge MA: NBER.

Malthus, T.R. 1964. Principles of Political Economy. New York: M. Kelley. First edition 1836.

Marshall, A. 1961. Principles of Economics. Cambridge: Macmillan. First edition 1890.

Marx, K. 1961. Capital. Moscow: Foreign Languages Publishing House. First edition 1867.

- 1969. Theories of Surplus Value. London: Lawrence \& Wishart. First edition 1905-1910.

Mayer, J. 2000. "Globalization, Technology Transfer and Skill Accumulation in Developing Countries. UNCTAD Discussion Paper, 150. Geneva: UNCTAD.

Melitz, M. 2003. “The Impact of Trade on Aggregate Industry Productivity and IntraIndustry Reallocations.” Econometrica, 71: 1695-1725.

Meschi, E., and M. Vivarelli. 2009. "Trade and Income Inequality in Developing Countries.” World Development, 37: 287-302.

Meschi, E., E. Taymaz, and M. Vivarelli. 2011. "Trade, Technology and Skills: Evidence from Turkish Microdata.” Labor Economics, forthcoming.

Milgrom, P., and J. Roberts. 1990. "The Economics of Modern Manufacturing: Technology, Strategy, and Organization.” American Economic Review, 80: 511-28.

1995. "Complementarities and Firms: Strategy, Structure and Organisational Change in Manufacturing." Journal of Accounting and Economics, 19: 179-208.

Mill, J.S. 1976. Principles of Political Economy. New York: M. Kelley. First edition 1848.

Morrison Paul, C.J., and D.S. Siegel. 2001. “The Impacts of Technology, Trade and Outsourcing on Employment and Labor Composition." Scandinavian Journal of Economics, 103: 241-64.

Neary, J.P. 1981. “On the Short-run Effects of Technological Progress.” Oxford Economic Papers, 32: 224-33.

Nickell, S., and B. Bell. 1995. "The Collapse in Demand for the Unskilled and Unemployment across the OECD.” Oxford Review of Economic Policy, 11: 40-62.

Nickell, S., and P. Kong. 1989. "Technical Progress and Jobs." Centre for Labor Economics. Discussion Paper 366. London: London School of Economics.

OECD, 1996. "The Evolution of Skills in OECD Countries and the Role of Technology. STI Working Paper 1996/8. Paris: OECD.

. 1998. "OECD Data on Skills: Employment by Industry and Occupation.” STI Working Paper 1998/4. Paris: OECD. 
Parisi, M.L., F. Schiantarelli, and A. Sembenelli. 2006. "Productivity, Innovation and R\&D: Microevidence for Italy” European Economic Review, 50: 2037-61.

Pasinetti, L. 1981. Structural Change and Economic Growth. Cambridge: Cambridge University Press.

Pavcnik, N. 2003. "What Explains Skill Upgrading in Less Developed Countries?" Journal of Development Economics, 71: 311-28.

Pavitt, K. 1984. "Patterns of Technical Change: Towards a Taxonomy and a Theory. Research Policy, 13: 343-74.

Perkins, R., and E. Neumayer. 2005. "International Technological Diffusion, Latecomer Advantage and Economic Globalization: A Multi-technology Analysis. Annals of the American Association of Geographers, 95: 789-808.

Peters, B. 2004. "Employment Effects of Different Innovation Activities: Microeconometric Evidence.” ZEW Discussion Papers, 0473. Bonn, Germany: ZEW.

Petit, P. 1995. "Employment and Technological Change.” In P. Stoneman (ed), Handbook of the Economics of Innovation and Technological Change. Amsterdam: North Holland.

Pianta, M. 2000. “The Employment Impact of Product and Process Innovations.” In M. Vivarelli and M. Pianta (eds), The Employment Impact of Innovation: Evidence and Policy. London: Routledge.

Pianta, M. 2005. "Innovation and Employment.” In J. Fagerberg, D. Mowery and R.R. Nelson (eds), Handbook of Innovation. Oxford: Oxford University Press.

Pianta, M., R. Evangelista, and G. Perani. 1996. "The Dynamics of Innovation and Employment: An international Comparison. STI Review, 18: 67-93.

Pigou, A. 1933. The Theory of Unemployment. London: Macmillan. . 1962. The Economics of Welfare. London: Macmillan. First edition 1920.

Piva, M. 2003. “The Impact of Technology Transfer on Employment and Income Distribution in Developing Countries: A Survey of Theoretical Models and Empirical Studies.” International Policy Group Working Paper 15. Geneva: International Labor Office (ILO).

Piva, M., E. Santarelli, and M. Vivarelli. 2005. "The Skill Bias Effect of Technological and Organisational Change: Evidence and Policy Implications.” Research Policy, 34: 141-57.

2006. Technological and organizational changes as determinants of the skill bias: Evidence from the Italian machinery industry. Managerial and Decision Economics, 27, 63-73.

Piva, M., and M. Vivarelli. 2001. "The Skill Bias in Italy: A First Report.” Economics Bulletin, 15, 1-8.

- 2002. "The Skill Bias: Comparative Evidence and an Econometric Test." International Review of Applied Economics, 16: 347-57.

- 2004. "Technological Change and Employment: Some Micro Evidence from Italy.” Applied Economics Letters, 11: 373-76.

- 2005. “Innovation and Employment: Evidence from Italian Microdata.” Journal of Economics, 86: 65-83. 
2009. "The Role of Skills as a Major Driver of Corporate R\&D.” International Journal of Manpower, 30: 835-52.

Ricardo, D. 1951. "Principles of Political Economy.” In P. Sraffa (ed), The Works and Correspondence of David Ricardo. Cambridge: Cambridge University Press. Vol. 1, third edition 1821.

Rifkin, J. 1995. The End of Work. The Decline of the Global Labor Force and the Dawn of the Post-Market Era. New York: G.P. Putnam's Sons.

Robbins, L. 1934. The Great Depression. London: Macmillan.

Robbins, D. 1996. "HOS Hits Facts: Facts Win; Evidence on Trade and Wages in the Developing World.” OECD Technical Paper, 119. Paris: OECD.

Robbins, D. 2003. "The Impact of Trade Liberalization Upon Inequality in Developing Countries: A review of Theory and Evidence.” ILO Working Paper, 13. Geneva: International Labor Organization.

Robbins, D., and T.H. Gindling. 1999. "Trade Liberalization and The Relative Wages for More-skilled Workers in Costa Rica.” Review of Development Economics, 3: 140-54.

Rosenberg, N. 1976. Perspectives on Technology. Cambridge: Cambridge University Press.

Salter, W.E.G. 1960. Productivity and Technical Change. Cambridge: Cambridge University Press.

Say, J.B. 1964. A Treatise on Political Economy or the Production, Distribution and Consumption of Wealth. New York: M. Kelley. First edition 1803.

Schiff, M., and Y. Wang. 2006. “On the Quantity and Quality of Knowledge: The Impact of Openness and Foreign R\&D on North-North and North-South Technology Spillovers." In B. Hoeckman and B.S. Javoricik (eds), Global Integration and Technology Transfer. New York: Palgrave Macmillan and World Bank.

Simonetti, R., K. Taylor, and M. Vivarelli. 2000. "Modeling the Employment Impact of Innovation." In M. Vivarelli and M. Pianta (eds), The Employment Impact of Innovation: Evidence and Policy. London: Routledge.

Sinclair, P.J.N. 1981. “When will Technical Progress Destroy Jobs?” Oxford Economic Papers, 31: 1-18.

Sismondi, J.C.L. 1971. Nouveaux Principes d'Economie Politique ou de la Richesse dans ses Rapports avec la Population. Paris: Calmann- Levy. First edition 1819.

Smolny, W. 1998. "Innovations, Prices and Employment: A Theoretical Model and an Empirical Application for West German Manufacturing Firms.” Journal of Industrial Economics, 46: 359-81.

Solow, R.M. 1960. "Investment and Technical Progress.” In K.J. Arrow, S. Karlin and P. Suppes (eds), Mathematical Methods in the Social Sciences. Stanford: Stanford University Press.

Standing, G. 1984. "The Notion of Technological Unemployment.” International Labor Review, 123: 127-47

Steuart, J. 1966. An Inquiry into the Principles of Political Economy. Chicago: Oliver and Boyd. First edition 1767. 
Stiglitz, J.E. 1987. "Learning to Learn, Localized Learning and Technological Progress.” In P. Dasgupta and P. Stoneman (eds), Technology Policy and Economic Performance. Cambridge: Cambridge University Press.

Stoneman, P. 1983a. The Economic Analysis of Technological Change. Oxford: Oxford University Press.

—. "New Technology, Demand and Employment." In D.L. Bosworth (ed), The Employment Consequences of Technological Change. London: Macmillan.

Sylos Labini, P. 1969. Oligopoly and Technical Progress. Cambridge MA: Harvard University Press. First edition 1956.

Taylor, L. 2004. "External Liberalization in Asia, Post-Socialist Europe and Brazil.” In E. Lee and M. Vivarelli (eds), Understanding Globalization, Employment and Poverty Reduction. New York: Palgrave Macmillan.

Van Reenen, J. 1997. "Employment and Technological Innovation: Evidence from U.K. Manufacturing Firms.” Journal of Labor Economics, 15: 255-84.

Venables, A.J. 1985. “The Economic Implications of a Discrete Technical Change.” Oxford Economic Papers, 37: 230-48.

Verhoogen, E.A. 2008. “Trade, Quality Upgrading, and Wage Inequality in the Mexican Manufacturing Sector.” The Quarterly Journal of Economics, 123: 489-530.

Vivarelli, M. 1995. The Economics of Technology and Employment: Theory and Empirical Evidence. Aldershot: Elgar.

—. 2004. "Globalization, Skills and Within-Country Income Inequality in Developing Countries." In E. Lee and M. Vivarelli (eds), Understanding Globalization, Employment and Poverty Reduction. New York: Palgrave Macmillan.

Vivarelli, M., and M. Pianta. 2000. The Employment Impact of Innovation: Evidence and Policy. London: Routledge.

Vivarelli, M., R. Evangelista, and M. Pianta. 1996. "Innovation and Employment in Italian Manufacturing Industry.” Research Policy, 25: 1013-26.

Welch, F. 1970. “Education in Production.” Journal of Political Economy, 78: 35-59.

Wicksell, K. 1961. Lectures on Political Economy. London: Routledge \& Kegan. First edition 1901-1906.

Wilson, D.J. 2009. "IT and Beyond: The Contribution of Heterogeneous Capital to Productivity.” Journal of Business and Economic Statistics, 27: 52-70.

Yeaple, S.R. 2005. "A Simple Model of Firm Heterogeneity, International Trade and Wages.” Journal of International Economics, 65: 1-20.

Zimmermann, K. 1991. "The Employment Consequences of Technological Advance: Demand and Labor Costs in 16 German Industries.” Empirical Economics, 16: 25366. 